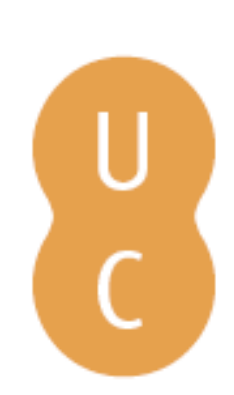

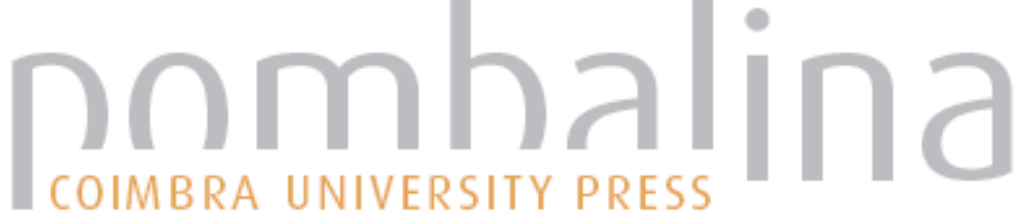

\section{Sweden: latin in Sweden}

Autor(es): Vidén, Gunhild

Publicado por: Imprensa da Universidade de Coimbra

URL

persistente: URI:http://hdl.handle.net/10316.2/38421

DOI: $\quad$ DOI:http://dx.doi.org/10.14195/978-989-26-0670-5_16

Accessed : $\quad$ 26-Apr-2023 15:00:10

A navegação consulta e descarregamento dos títulos inseridos nas Bibliotecas Digitais UC Digitalis, UC Pombalina e UC Impactum, pressupõem a aceitação plena e sem reservas dos Termos e Condições de Uso destas Bibliotecas Digitais, disponíveis em https://digitalis.uc.pt/pt-pt/termos.

Conforme exposto nos referidos Termos e Condições de Uso, o descarregamento de títulos de acesso restrito requer uma licença válida de autorização devendo o utilizador aceder ao(s) documento(s) a partir de um endereço de IP da instituição detentora da supramencionada licença.

Ao utilizador é apenas permitido o descarregamento para uso pessoal, pelo que o emprego do(s) título(s) descarregado(s) para outro fim, designadamente comercial, carece de autorização do respetivo autor ou editor da obra.

Na medida em que todas as obras da UC Digitalis se encontram protegidas pelo Código do Direito de Autor e Direitos Conexos e demais legislação aplicável, toda a cópia, parcial ou total, deste documento, nos casos em que é legalmente admitida, deverá conter ou fazer-se acompanhar por este aviso.

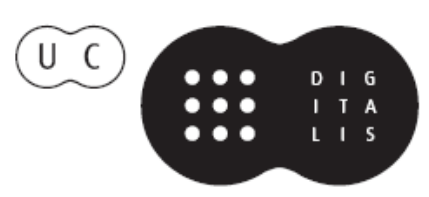


Gunhild Vidén ${ }^{1}$ - University of Gothenburg

gunhild.viden@gmail.com

\section{SWE D E N}

\section{A T I N I N S W E D E N}

\section{Introduction}

\subsection{The Middle Ages}

The first contact with Latin culture came with the christianization of Sweden. The first missionary was Ansgar (801-865), also known as "the apostle of the North", who was sent out from the see of Hamburg to the city of Birka in Mälaren (close to present day Stockholm). This first attempt at christianization seems to have been of short duration, but from ca 1000 Sweden became a Christian nation. Descriptions of the Nordic countries can be found in Adam of Bremen's Gesta hammaburgensis ecclesiae pontificum from ca 1070. With the introduction of monasteries a school system came into being, and the monastery and cathedral schools were of course Latin speaking. From the $13^{\text {th }}$ century we hear of Swedish students visiting the university of Paris. The first Latin text by a Swedish hand that has been preserved to us is the biography of the Beguin Christina of Stommeln, written by the monk Petrus de Dacia (c 1230-1289), together with a correspondence between Petrus and Christina.

\footnotetext{
${ }^{1}$ In cooperation with Hans Aili, prof. emeritus of Latin, University of Stockholm, hans. aili@klassiska.su.se; Hans Helander, prof. emeritus of Latin, University of Uppsala, hans. helander@lingfil.uu.se; Ann-Mari Jönsson, docent of Latin, editor of the Linneaus project, http://linnaeus.c18.net/.
} 
The internationally most renowned Swede from the Middle Ages is in all probability St. Brigid (c. 1303-1373). Brigid, who belonged to the upper classes, was literate, but, being a woman, she did not know Latin. Her revelations, which she received in a state of ecstasy, were written down in Swedish (a couple of autographs are preserved) but were translated into Latin by her confessors. Her revelations quite frequently deal with political matters of the day, giving instructions to both king and pope. The latter was admonished to leave the exile in Avignon and return to Rome, and it was probably with great pleasure that she met with Urban $\mathrm{V}$ in Rome in 1367. She received permission to found an order, which still exists (partly refounded in the $20^{\text {th }}$ century).

Other Latin texts from the Middle Ages are e g sermons, orations, monastery diaries, correspondence and juridical documents. Modern scholarly editions of such texts are being issued by Swedish scholars, e g within the Diplomatarium Suecanum, hosted by the Swedish National Archive (http://www.riksarkivet.se/).

\subsection{The Reformation}

The reformation meant a break in the cultural life of Sweden, when monasteries were closed down and libraries were dispersed. At the same time, Sweden was brought closer to the secular erudition of the rest of Europe. Gustavus I, the king who turned Sweden into a Lutheran country, was eager for his court to become a renaissance court that could stand comparison with any court in Europe, and his three sons received a good education. His eldest son and successor, Erik XIV, was a good Latinist who, among other things, wrote a letter of proposal to Queen Elisabeth I of England in highly rhetorical Latin. The $16^{\text {th }}$ century saw a number of Swedish poets who wrote secular Latin poetry, in emulation and imitation of ancient poets and above all Virgil.

The internationally most well-known authors in this period were the brothers Johannes and Olaus Magnus. Johannes Magnus was the last catholic archbishop of Sweden, and after a decision in the parliament 1527 that 
was the start of the lutheranization of the Swedish church, the two brothers left Sweden never to return. Olaus Magnus is the author of Historia de gentibus septentrionalibus, a work which is not only a history but also an ethnographic description of Sweden. Johannes Magnus wrote Historia de omnibus gothorum suenonumque regibus, where he created a fictional glorious past for Sweden, increasing its list of monarchs with a number of fictional kings by the names of Erik and Karl, and also wrote disparaging descriptions of fictional kings with obvious similarities to King Gustavus I. This work became the starting point for the later so called Gothic movement, with Olof Rudbeck's Atlantica (1679) as its opus magnum.

\section{3. $17^{\text {th }}$ and $18^{\text {th }}$ century}

In the $17^{\text {th }}$ century Latin remained the language for international contacts, not least within diplomacy. A French embassy to the court of Queen Christina, who were tactless enough to address the Queen and the chancellor Axel Oxenstierna in French instead of in Latin, got an answer in Swedish, although Oxenstierna spoke both French and Latin fluently. Latin was still the literary language par préférance, but literature in the vernacular began to appear. The so called "father of Swedish literature", Georg Stiernhielm, wrote in both Latin and Swedish and was an excellent Latinist. Gradually, the Swedish language took over in literature, and during the $18^{\text {th }}$ century French became the international diplomatic language. Latin remained the language of the scholarly world, with the new universities as the centres. All scholarly work was produced in Latin, but during the $18^{\text {th }}$ century this was disputed by some people. The idea was that matters concerning Swedish national interests, such as mining, should be presented in Swedish. The arguments against were that the Swedish language did not lend itself to scholarly matters. Gradually, however, dissertations in Swedish began to appear, but for a long time Latin remained the lingua franca for all scholars. Linné, the famous botanist, is a good example of this. Linné's scholarly work, including his international correspondence, is in Latin, whereas his more popular 
descriptions of the Swedish landscape (from his travels around Sweden) are in Swedish but with frequent Latin words and phrases. Latin is still used in plant taxonomy. Emanuel Swedenborg was a scientist before becoming a Christian mystic, and it was natural for him to write in Latin whatever the theme of his presentation. Scholars wrote for the res publica literaria, not for their fellow countrymen, and thus chose the language they all had in common.

Worth mentioning is also the poet Sofia Elisabeth Brenner, who wrote poetry in six different languages including Latin.

\subsection{Later development}

Gradually, the modern languages succeeded Latin not only as a literary language but also in the scientific world. It is possible to find Latin texts produced in Sweden in the $20^{\text {th }}$ or $21^{\text {st }}$ centuries, such as jocular translations of well-known songs into Latin (e g Senex Noa, a translation of one of the most well-known songs by the $18^{\text {th }}$ century poet Carl Michael Bellman), or academic orations, but in the main Latin must be said to have lost its position as a literary language or a language for international communication. Latin is still popular in solemn contexts (inscriptions in rings, wedding telegrams etc), and a quite new phenomenon is tattoos in Latin. It seems that even if Latin is considered a "dead" language by many people, ideas of its eternity are frequent not only among its learners.

\section{Birgitta}

St. Bridget, born ca. 1303, is one of very few famous women from the Middle Ages. The daughter of a sheriff (Sw. "lagman") and married to another, she belonged to the upper circles of society. She was in close contact with the Swedish royal court and served under Queen Bianca of Namur. She became the mother of 8 children. Together with her husband Ulf she made a pilgrimage to Santiago de Compostela, and after his death 
she settled in Rome, where the Casa S:a Brigida is today a Brigittine monastery. She died 1373, shortly after a pilgrimage to Jerusalem, and was sanctified in 1391. All during her life she had revelations where she experienced Christ and the Virgin Mother speaking to her. These revelations vary as to their content; not infrequently they deal with contemporary political issues where St Bridget is asked to deliver messages from Christ to e.g. the Pope or the Swedish king.

The revelations were translated from Swedish into Latin by Bridget's Swedish confessors, both by the name of Petrus. They were later revised in Italy by her Spanish confessor Alfonso, bishop of Jaén. Two excerpts from her works have been chosen. The first one is from book 7, a revelation from her pilgrimage to Bethlehem, where she witnesses the Virgin giving birth to Jesus. The second is from book 6, where Pope Clement VI is instructed to make peace between England and France and arrange an annus jubilaeus.

The spelling has partly been normalized according to classical orthography (the original has e for ae, -ci- for -ti-). Sponsa is Bridget's word for herself in the revelations:

Visio, quam habuit domina Birgitta in Bethleem, ubi virgo Maria ostendit ei totum modum sui partus, qualiter ipsa peperit gloriosum filium suum, sicut ipsa virgo promiserat eidem dominae Birgittae in Roma, antequam iret ad Bethleem per XX annos, ut patet in primo capitulo istius libri ultimi. Cap. XXI.

1 Cum essem ad praesepe Domini in Bethleem, vidi quandam virginem praegnantem pulcherrimam valde, indutam albo mantello et subtili tunica, per quam abextra eius carnes virgineas clare cernebam. 2 Cuius uterus plenus et multum tumidus erat, quia iam parata erat ad pariendum. Cum qua senex quidam honestissimus erat et secum habebant ambo unum bovem et asinum. 3 Qui cum intrassent speluncam, senex ille ligatis bove et asino ad praesepe exivit extra et portavit ad virginem candelam accensam fixitque eam in muro et exivit extra, ne partui personaliter interesset. 4 Virgo igitur illa tunc discalciavit calciamenta pedum suorum et discooperuit mantellum album, quo cooperiebatur, amovitque velum de capite suo et iuxta se reposuit ea, remanens in sola 
tunica, capillis pulcherrimis quasi de auro extentis super spatulas. 5 Quae tunc duos panniculos lineos et duos laneos mundissimos et subtiles extraxit, quos secum portabat ad involvendum nasciturum infantem, et duos alios paruulos lineos ad cooperiendum et ligandum caput illius, ipsosque posuit iuxta se, ut eis uteretur tempore debito.

6 Cumque haec omnia sic parata essent, tunc virgo genuflexa est cum magna reverentia, ponens se ad orationem, et dorsum versus praesepe tenebat, faciem vero ad caelum levatam versus orientem. 7 Erectis igitur manibus et oculis in caelum intentis stabat quasi in extasi contemplationis suspensa, inebriata divina dulcedine. 8 Et sic ea in oratione stante vidi tunc ego movere iacentem in utero eius, et illico in momento et ictu oculi peperit filium, a quo tanta lux ineffabilis et splendor exibat, quod sol non esset ei comparabilis. 9 Neque candela illa, quam posuerat senex, quoquomodo lumen reddebat, quia splendor ille diuinus splendorem materialem candelae totaliter annichilaverat. 10 Et tam subitus et momentaneus erat ille modus pariendi, quod ego non poteram advertere nec discernere, quomodo vel in quo membro pariebat. 11 Verumtamen statim vidi illum gloriosum infantem iacentem in terra nudum nitidissimum. Cuius carnes mundissimae erant ab omni sorde et immunditia. 12 Vidi etiam pellem secundinam iacentem prope eum, involutam et valde nitidam. Audivi etiam tunc cantus angelorum mirabilis suavitatis et magnae dulcedinis. 13 Et statim venter virginis, qui ante partum tumidissimus erat, retraxit se et videbatur tunc corpus eius mirabilis pulchritudinis et delicatum.

14 Cum igitur virgo sensit se iam peperisse, statim inclinato capite et iunctis manibus cum magna bonestate et reverentia adoravit puerum et dixit illi: "Bene veneris, Deus meus, Dominus meus et filius meus!" 15 Et tunc puer plorans et quasi tremens prae frigore et duritia pavimenti, ubi iacebat, volvebat se paululum et extendebat membra, quaerens invenire refrigerium et matris favorem. 16 Quem tunc mater suscepit in manibus et strinxit eum ad pectus suum, et cum maxilla et pectore calefaciebat eum cum magna laetitia et tenera compassione materna. 17 Quae tunc sedens in terra posuit filium in gremio et recepit cum digitis subtiliter umbilicum eius, qui statim abscisus est, nec inde aliquis liquor aut sanguis exivit. 18 Et statim coepit eum involvere diligenter, primo 
in panniculis lineis et postea in laneis et stringens corpusculum, tibias et brachia eius cum fascia, quae suta erat in quatuor partes superioris panniculi lanei. 19 Postea vero involvit ligando in capite pueri illos duos panniculos lineos, quos ad hoc paratos habebat. 20 His igitur completis intravit senex, et prosternens se ad terram genibus flexis adorando eum plorabat prae gaudio. $21 \mathrm{Nec}$ tunc in partu virgo illa immutabatur colore vel infirmitate, nec in ea defecit fortitudo aliqua corporalis, sicut in aliis mulieribus parientibus fieri solet, nisi quod venter eius tumidus retraxit se ad priorem statum, in quo erat, antequam puerum conciperet. 22 Tunc autem surrexit ipsa, habens puerum in ulnis suis, et simul ambo, scilicet ipsa et Ioseph, posuerunt eum in praesepio et flexis genibus adorabant eum cum gaudio et immensa laetitia.

Christus dat sponsae verba bic contenta et praecipit illa mittere papae Clementi, scilicet quod faceret pacem inter reges Franciae et Angliae et quod veniret in Italiam et annuntiaret annum iubilaeum. Reprehendit quoque eum Christus de certis peccatis et negligentiis gravibus et de vita praeterita inordinata et comminatur ei cum iustitia, nisi se correxerit. Cap. LXIII.

1 Filius loquitur ad sponsam: "Scribe ex parte mea papae Clementi haec verba: Ego exaltavi te et ascendere te feci super omnes gradus honoris. Surge igitur ad faciendum pacem inter reges Franciae et Angliae, qui sunt periculosae bestiae, animarum proditores. 2 Veni deinde in Italiam et praedica ibi verbum et annum salutis et dilectionis divinae et vide plateas stratas sanctorum meorum sanguine, et dabo tibi mercedem illam, quae non finietur. 3 Attende etiam ad tempora priora, in quibus audacter ad iram provocasti me et silui, in quibus fecisti, quae voluisti et non debuisti et ego quasi non iudicans patiens fui. 4 Quia tempus meum nunc appropinquat et exquiram a te negligentiam et audaciam temporis tui. Et sicut per omnes gradus ascendere te feci, sic descendes spiritualiter per alios gradus, quos experieris veraciter in anima et corpore, nisi oboedieris verbis meis. 5 Et silebit lingua tua magniloqua, et nomen tuum, quod vocasti in terris, in oblivione et obprobrio erit in conspectu meo et sanctorum meorum. Exquiram etiam a te, quam indigne (permissione tamen mea) ad 
omnes gradus ascendisti, quod melius ego Deus scio, quam tua negligens conscientia recordatur. 6 Quaeram quoque a te, quantum in reformatione pacis regum tepuisti et quantum in aliam partem declinasti. Insuper non erit in oblivione, qualiter cupiditas et ambitio in Ecclesia tempore tuo floruit et aucta est, et quod multa reformare et emendare potuisti sed tu, amator carnis, noluisti. 7 Surge igitur, antequam novissima bora tua appropinquans veniat, et negligentias priorum temporum paenultimo tempore zelando extingue! Si autem dubitas, cuius spiritus verba ista sint, ecce regnum et persona nota sunt, in quibus stupor et mirabilia facta sunt. 8 Iustitia enim et misericordia, de quibus loquor, appropinquant ubique terrarum, conscientia quoque tua rationabile dicit esse illud, quod moneo, et caritativum esse, quod suadeo. 9 Et nisi patientia mea servasset te, iam profundius ultra alios praedecessores tuos descendisses. Ergo inquire in libro conscientiae tuae et vide, si veritatem loquor!"

\section{Olaus Magnus}

Olaus Magnus, 1490-1557, was together with his brother Johannes one of the most learned Swedish church officials in Sweden in the 16th century. As an opponent of the reformation he became an adversary of the Swedish king Gustavus Vasa, and lived de facto in exile together with his brother from 1527 until his death. After his brother's death in 1544 he was appointed Arch Bishop of Sweden by the Pope, but was never able to return to Sweden. He established himself in St. Bridget's house in Rome, where he opened a printer's office and printed both legends about St. Bridget, as well as his brother's and his own works.

Olaus Magnus' fame as a learned man rests on two works: the Charta Marina, a map of the Nordic countries printed in Venice in 1539, and the Historia de gentibus septentrionalibus, History of the Nordic peoples, printed in 1555. This work is rather an ethnographic description of the Nordic countries, and is thus valuable as a source to the culture of Medieval Scandinavia even today. For a long period after its publication, it remained the main source of knowledge about Scandinavia in Europe. 
The excerpt chosen here describes a winter game that is practiced in Sweden to this day: the building of fortresses of snow:

De castellis nivalibus iuvenum

Mos est Septentrionalium populorum, provida quadam sagacitate adolescentes diversis bellandi exercitiis et artibus castella impugnandi exercere et excitare, quibus praesertim tyrocinia sine caede et sanguine ac quovis vitae periculo haec aggredi putant voluptuosum; et ob id quotannis byeme durantibus nivibus, loco aliquo eminenti turmatim a maioribus excitati congrediuntur adolescentes, conformi labore immensas nivium moles comportantes; e quibus propugnacula ad formam castrensium moeniorum feriatis saltem diebus solicite fabricant, aqua structuram huiusmodi fenestris distinctam continuo aspergentes, ut nix cum aqua taliter congesta accedente frigore validius induretur. Qua diligentia adeo fortificantur, ut non solum leves ictus sed aereos globos atque impulsum testudinum (quatenus opus esset) possent sustinere. Quibus paratis, adolescentes praedicti in diversas turmas segregate, pars moenia ingreditus contuenda, pars foris remanet eadem impugnanda. Nec desunt in candidis castris atra seu fusca vexilla, aut virides iuniperorum rubi sub quibus non pecuniae sed solius laudis appetitu voluptuosum ingrediuntur certamen: quod aliis armis utrobique non committitur, nisi niveis globis in alterutrum e manibus proiectis. Statuta enim poena est nudi corporis in gelidam aquam immergendi, ne quis globis huiusmodi nivalibus faxum, ferrum, lignum, aut glaciem proiecturus involvat.

(Olaus Magnus I. XXIII)

\section{Emanuel Swedenborg}

Emanuel Swedenborg (1688-1772) was a scientist, a Bible exegetic and a theosophist. After a career within the natural sciences he turned to 
religious mysticism, having had a vision as the culmination of a religious crisis in 1745. The spiritual world became his object of research, which was carried out within the same theoretical framework that he had used in his earlier scientific work. His theory of correspondence has had great influence on posterity. A Swedenborg Church still exists in Sweden and in a number of English-speaking countries.

The excerpts are chosen from Swedenborg's De cultu et amore Dei from 1745, the first part of the introduction and the beginning of its first chapter:

\section{Introductio}

Cum solus quondam in luco urbano, cogitationum turbas discutiendi gratia, obambularem, ac viderem viduari foliis arbores, et caducas circumvolitare frondes (autumnus enim tunc devebebat annum et aestatis decoramenta decutiebat), ex tristi serius factus sum, quia recordabar amoenitatum, quas nemoretum illud a suo vere ad hanc usque temporis versuram communes habuit, et in meum quoque animum toties effudit: at visa hac altera scena, coepi temporum vices volvere; et subiit, annon omnia, quae sunt temporis, similes etiam vices percurrant; scilicet, non solum sylvae, sed quoque vitae nostrae, ac aetates; nam consimiliter illas a vere et flore quodam auspicatas, exacta aestate, in suam senectam, autumni imaginem, proclives labi, cernimus. Nec solum aetates, sed etiam saecula aut aeva, id est, communes societatum vitas, quae ab infantia, integritate et innocentia, olim aureae ac argenteae, dictae sunt; et nunc ultimas seu ferreas ad ostium affore, brevi in ferruginem aut argillae pulverem dilapsuras, creditur.

Caput primum, sectio prima de ortu telluris

Circum circa solem, huius universi centrum, terrestris noster globus, sicut orbita, quotannis volvitur, et gyri sui dimensa per sidera in zodiaco, quae praetervebitur, designat: tempus eius circuitionis 
aut reditus ad idem circuli punctum dicitur eius annus. Dum gyrum bunc aut annum currit, oblique paulo versus triones, et deorsum illis ex opposito, a magno circulo aequidiali, divertitur; et sic in quovis suo minimo gressu, ubivis loci, varium solis aspicit vultum, inde eius quatuor anni spatia, scilicet ver, aestas, autumnus et byems. In hac sua circumvolutione, non secus ac rota, circum axem, qui a polo ad polum per medium aequinoctialem circulum seu aequatorem percurrit, vertitur, et per hos versus currentem peripheriam secat in partus aut gradus, qui anni eius dies nuncupantur. In singulis his per rotationem facit oriri solem, et ab ortu in altum surgere, indeque delabi, ac demum occidere et absondi; inde cuiusvis diei iterum quatuor tempora, matutinum, meridianum, vespertinum, et nocturnum; una cum suis horis, quae quasi diem bunc circumstant, et anni temporum tempora mensurant. Quatuor intervalla cuiusvis diei in quatuor intervallis totius anni se sicut effigies minores in magnis repraesentant; se nimirum aurora in vere, meridies in aestate, autumnus in vespere, et byems in nocte, et sic porro.

\section{Carl von Linné}

Carl von Linné, the famous Swedish botanist and founder of the sexual system and of a uniform terminology for plant descriptions, was born in 1707 and died 1778. He was a professor of theoretical medicine at the university of Uppsala, which formed the basis for his scientific work. Besides his scholarly studies in Latin (e. g. Systema naturae; Genera plantarum; Fundamenta botanica; Flora Lapponica; Philosophia botanica; Species plantarum) he also wrote travel books in Swedish from his different journeys around Sweden where he studied not only plants but also customs, buildings etc. He corresponded with leading scholars in Europe, and a large part of this correspondence is preserved.

The following text is a letter from Linné to Albrecht von Haller, Swiss scientist and botanist, written in 1739 and containing some information about Linné's personal life: 
Viro inclyto, Botanico Celeberrimo, Alberto Hallero, Professori Clarissimo, s pl d Carolus Linnaeus.

Litterae Tuae (mihi omni auro chariores) datae d. 24 Novembris 1738 accessere ad me hoc anno die 12 Augusti per concionatorem Ecclesiae Germanicae, Holmiae instructum; fatum morae mibi latet.

Extuli millies Hermanni manes; parum fuit saliisse fontes omnes Horti Regis Gallorum ad accessum Hermanni, jubente Tournefortio, si generosum Hermanni animum cum Tournefortiano conferas. Hermannus Tournefortio antea obtulit professionem botanicam, quam alio commutaret, quo viveret Tournefortius; quid itaque de Te dicam ipse; peregrinum amas, vocas, professoriam dignitatem et munus et hortum fere offers; vix frater fratri, vix pater hoc filio unico. Uno verbo plures mortales vidi, multi me amarunt; nullus mibi obtulit tanta, quanta Tu. Verbis grates redderem, si possem, sed nequeo digna reddere verba; sancta mente servabo, dum vixero, et alii post me, tuum nomen.

Non respondeo, cum Tu Te patrem praestes, ego filius; dabo en bistoriam qualemcunque vitae meae in bunc usque diem. Anno 1730 docui Botanicen, Horto Botanico Upsaliensi; redit eodem anno amicus noster communis, D(ominus) D(octor) Rosen; ego studiosus medicinae vicarius eram Rudbeckii in Botanicis, ille in Anatomicis, et simul adjunctus Medicinae; An. 1732 adii Lapponiam, redii, docui docimasticen et Botanicen per annum unicum; discessi Upsalia, iter ingressus sum Dalekarliam, sic providente Deo; facto itinere redii in primariam urbem istius provinciae Dalekarlicae Fahlunam, docui Mineralogiam, praxin exercui minimam: amatus ab omnibus permansi per mensem. Erat ibi medicus, quem divitem dicere non erubescebat vulgus; imo erat inter omnes in ista pauperrima provincia ditissimus nomine Moraeus, vir etiam inter Sueciae medicos, doctrinam si spectes, facile primus. Vir iste nullum vitae genus medicinae inferiorem (praxin bic spectans) esse, millies pronunciavit; me interim amabat. Adii domum ejus non semel gratus ipsi hospes; filiam habuit (et aliam aetate inferiorem) pulchram, quam ambiebat Liber Baro quidam frustra; vidi, obstupui, praecordia intima sensi attonitus novis intumuisse curis. Amavi, illa, tandem victa 
blanditiis, votis, etc. et me amabat, promisit, dixit: fiat! Patrem adloqui erubescebam pauperrimus; dixi tamen; voluit et noluit; me amabat pater, non mea fata, dixit: intacta permanebit per tres annos, dicam tum demum compositis rebus; ad iter necessaria paratis exivi patriam 36 nummis aureis dives. Promotionem medicam mox obtinui; redire magno meo cum commodo non potui; permansi in Belgio, ut novisti; interim amicus meus summus, Cl. B(rowallius) litteras amicae meae ad me per tabellarios continuo transmittebat; sancte praestitit; ultimo anno 1738 , quo apud $v$. Royen vixi (quod erat quarto anno, non enim socer plures quam tres concessit annos et boc quidem nutu sponsae), sibi proximum judicavit B(rowallius) esse, mea enim recommendatione factus fuit Professor; mox me non reversurum in patriam demonstrabat; sponsam meam ambiebat; fere obtinuit, ni intervenisset alius, fallaciam qui prodidit; punitus et ipse fuit mille fatis adversis.

Redii tandem, sed pauper. Puella me amabat, non illum; sedem fixi Holmiae, irrisus ab omnibus ob meam Botanicen. Quot insomnes noctes et laboriosas horas transegerim, nullus dixit, quam vero a Siegesbeckio eram annibilatus, omnes uno ore acclamabant; non erat qui vel servum mibi curandum obtulit. Transegi vitam quocunque possem modo, tamen honeste: incepi praxin exercere valde lente; sed brevi fata cessabant adversa, et post diuturnas nebulas Phoebus; emersi, ad primates accersitus, cessere omnia secunde, nullus aeger sanabatur, me non praesente; pecunias accepi; ab hora quarta matutina in seram vesperam aegros adii, noctes apud aegros consumsi; heu, dixi, dat Aesculapius bona omnia, Flora vero solos Siegesbeckios; interdixi Floram; quae collegi adversaria (beu nimis multa) aeterno pulvere sepelienda millies decrevi; Siegesbeckio nunquam responsurum fere juravi: mox primarius medicus Classis navalis constitutus fui; conventus civium mox me Botanicum Regium, publice quo docerem Botanicen in Regia sede Stockholmiae, dixere, stipendio annuo auxerunt. Incepi iterum amare plantas. Sponsam adii tum meam quinquennem, tam dignus thalamum intravi sponsae et uxoris. Socer tamen sat pecuniis ipse delectatur, nec generi facile concedit; sed nec opus habeo; et quis a me generetur, habebit. 
Nunc vero utraque Professio Medicinae vacabit; ambo senes Professores Rudbeck et Roberg dimissionem ambiunt; quod si fiat, forte Cl. Rosen erit successor Robergii, forte ego Rudbeckii; sin secus, Stockholmiae et vivere et mori cupio; nec competitoris defendam spartam. Sin vero Botanices Professio Upsaliae mea non fiat, et me tum (post tres menses) vocares, accederem, si cum uxorcula daretur. Vel si aliquando Te videre liceret Hamburgi, hanc unicam ob causam Hamburgum adirem, licet longe sepositus vivo. Tanti te facio, utinam ante fata Tecum loqui contigisset et Te coram videre! Vale, vive diu felix artis nostrae fidus.

Dabam Stockholmiae, 1739 die 12 Septembr[is].

\section{Bibliography}

Hans Aili, Olle Ferm, Helmer Gustavson (eds), Röster från svensk medeltid: latinska texter $i$ original och översättning. Stockholm 1990.

E. Malmeström \& A. Hj. Uggla, Vita Caroli Linnaei. Carl von Linnés självbiografier. På uppdrag av Uppsala universitet utgivna. Uppsala 1957.

Pars prima de Cultu et Amore Dei, ubi agitur de Telluris Ortu, Paradiso E Vivario, tum de Primogeniti seu Adami Nativitate, Infantia, \& Amore. Ab E. Swedenborg, Toronto 2009 (Londini 1745; repr. by Tho M. Gorman, Londini 1883).

Sancta Birgitta. Revelaciones Lib. VII. Ed. by B. Bergh. Uppsala 1967. 